\title{
THE EXCLUSION OF EVIDENCE OBTAINED BY ENTRAPMENT: AN UPDATE
}

\author{
Darren Subramanien
}

\author{
LLB LLM
}

Lecturer, University of KwaZulu-Natal

Pietermaritzburg

Nicci Whitear-Nel

$B A L L B$

Senior Lecturer, University of KwaZulu-Natal

Pietermaritzburg

\section{SUMMARY}

This article provides an update on the exclusion of evidence obtained as a result of entrapment. The exclusion of such evidence in terms of section 252A of the Criminal Procedure Act, section 35(5) of the Constitution of the RSA Act, and in terms of the common law, are examined. Two recent Supreme Court of Appeal cases $-S v$ Kotze and $S \vee$ Zurich - are specifically discussed.

\section{$1 \quad$ INTRODUCTION}

\section{What is entrapment?}

Entrapment occurs when an opportunity for the commission of an offence is created for the specific purpose of securing evidence, in order to obtain a conviction. It necessarily involves a degree of deception, and sometimes the law enforcement officer conducting the trap is ostensibly also involved in the illegal activity. ${ }^{1}$ Because of these features, there is a concern that the technique can be abused, and that people who would otherwise not commit a crime, may be unfairly tempted into doing so. ${ }^{2}$

S v Malinga 19631 SA 692 (A) 693F-G; S v Tsochlas 19741 SA 565 (A) 574B. Also see Bronstein "Unconstitutionally Obtained Evidence: A Study of Entrapment" 1997114 SALJ $108109-110$, who argues that this is too narrow a definition of entrapment. She refers to Dworkin's taxonomy of five archetypal traps in support of her position (Dworkin "The Serpent Beguiled Me and I Did Eat: Entrapment and the Creation of Crime" 19854 Law and Philosophy 17 17-21). Also see $S v$ Lachman 20102 SACR 52 SCA, for an example of an undercover operation.

2 Sv Kotze 20101 SACR 100 SCA 104 par 3. 
During the apartheid era, courts generally did not exclude evidence obtained as a result of unfair entrapment. However, the fact that the conviction was based on such evidence was regarded as a factor-mitigating sentence. ${ }^{3}$ Bronstein makes the interesting point that this trend must be understood in the context of South Africa's history, where the apartheid police force was despised and thus could not rely on cooperation from the community to solve crime. ${ }^{4}$ Despite this general trend, there were a significant number of courts which expressed concern at the unfair use of entrapment to secure convictions. ${ }^{5}$ Legal commentators - both locally and internationally - have also expressed concern. ${ }^{6}$

Against this background, the South African Law Commission undertook an investigation and prepared a report on the use of evidence obtained as a result of entrapment, and used to secure criminal convictions. ${ }^{7}$ The Commission rejected the notion that the fact that the crime was committed as a result of entrapment could ever be a defence to a charge of criminal conduct. ${ }^{8}$ Instead, it endorsed the view that the use of entrapment to secure evidence should be controlled through rules, excluding such evidence in certain circumstances. ${ }^{9}$ This approach seeks to balance society's interest in seeing criminals brought to book, with the need to protect the integrity and legitimacy of the criminal justice system, and the individual's constitutional rights. ${ }^{10}$

\section{CRIMINAL PROCEDURE ACT}

Following from the Law Commission's work, section 252A of the Criminal Procedure Act ${ }^{11}$ was enacted. ${ }^{12}$ Section $252 \mathrm{~A}$ regulates the admissibility of

3 Terblanche Guide to Sentencing in South Africa (2007) 194. See also S v Hassen 19971 SACR 247 248a-b, where the court stated that it was trite that there was neither a defence of entrapment, nor an exclusionary rule or general discretion to exclude evidence as a result of entrapment (compare with cases in footnote 49).

4 Bohler "Lead us Not into Temptation: The Criminal liability of the Trappee Revisited" 1999 12 SACJ 317.

5 See, eg, the court in $S$ v Ohlenschlager 19921 SACR 695 (T); S v Nortje 19962 SACR 308 (C) 317-8; and S v Pule 19962 SACR 604 (O).

6 See, eg, Heydon "The Problems of Entrapment" 1973 32(1) Cambridge LJ 268; Harris "Entrapment" 1994 18(4) Criminal LJ 197; Squires "The Problem with Entrapment" 2006 26(2) Oxford Journal of Legal Studies 351-376; Stegmann "A Point at Which the Law and Morality May Part" 1991108 SALJ 688; Naude "Voorafgaandemagtiging as Vereiste vir Lokvalbetrapping" 199811 SACJ 213; Hoctor "Dignity, criminal law and the Bill of Rights" 2004121 SALJ 304 315; and Engelbrecht "Die lokvalstelsel: Quo Vadis" 1988 De Rebus 685.

7 Report on The Application of the Trapping System SA Law Commission Working Paper 52 , Project 84 of 1993. See Louw "Police Traps" 19958 SACJ 286 for an analysis of the report.

8 This approach is discussed in Le Roux "'n Les Uit Eden: Onbillike Lokvalle en Strafregtelike Skuld" 199710 SACJ 3; Engelbrecht 1988 De Rebus 685; and Labuschagne "Die Verweer van Lokvinkbetrapping: 'n Straftelike Herwaardering" 19936 SACJ 208.

9 Report on The Application of the Trapping System SA Law Commission Working Paper 52 , Project 84 of 1993112 par 21.

10 For a discussion on the relative merits of the two different approaches, see Du Toit, De Jager, Paizes, Skeen and Van der Merwe Commentary on the Criminal Procedure Act (2010) 24-133/134.

1151 of 1977 , hereinafter "the CPA" and "Section 252A", respectively. 
evidence obtained through entrapment, undercover operations and related matters. ${ }^{13}$ The section differs in material respects from that proposed by the Law Commission. ${ }^{14}$ It codifies many of the factors which had regulated the classification of trap as either fair or unfair, at common law. ${ }^{15}$ The Supreme Court of Appeal (SCA) has held that it is incorrect to understand section $252 \mathrm{~A}$ as only authorising traps in certain circumstances. ${ }^{16}$ Instead, section $252 \mathrm{~A}$ provides that in certain circumstances, evidence obtained as a result of entrapment will be automatically admissible ${ }^{17}-$ while in others the court will have a discretion to either admit or exclude it. ${ }^{18}$

The poor drafting of section $252 \mathrm{~A}$ has been much commented on, ${ }^{19}$ and there has been a judicial recommendation that it be amended. ${ }^{20}$ However, the legislature has not responded by doing so.

\section{Section 252A(1)}

Section $252 \mathrm{~A}(1)$ only applies to traps carried out by a law enforcement officer, official of the state, or any other person authorised thereto for such purpose. The provisions of section 252A, thus do not apply to traps conducted by private persons. ${ }^{21}$ Private trapping occurs most frequently in the context of the employment relationship, where the employer seeks evidence of an employee's misconduct. Despite the fact that section 252A does not apply to such trapping, the labour court has held that, given the concerns expressed about entrapment by the courts and the legislature, guidelines and parameters no less rigid than those set out for the criminal law, should be applied in the employment context. ${ }^{22}$

12 Per Criminal Procedure Second Amendment Act 85 of 1996. The section came in effect on 29 November 1996.

13 The SCA in $S v$ Kotze distinguished between a trap and undercover operation, holding that the latter may not involve a trap. An undercover agent may, eg, simply infiltrate a gang to obtain information. Also see S v Lachman 20102 SACR 52 SCA, where the accused himself instigated the incriminating transaction, which was participated in by the trap, only to secure the necessary evidence to prosecute the crime. Such conduct will invariably fall within the ambit of section $252 \mathrm{~A}(1)$, and thus be regarded as automatically admissible subject to a constitutional or common-law challenge. See later discussion.

14 Report on The Application of the Trapping System SA Law Commission Working Paper 52 , Project 84 of 1993105 par 3.

15 For relevant cases decided in terms of the common law, see $R v$ Clever; $R v$ Iso 19674 SA 256 (RA); S v Van Pittius 19733 SA 814 C; S v Pallis 19761 SA 235 (RA); S v Pektar 1988 3 SA 571 A; $S$ v Ohlenschlager 19921 SACR 695 (T); and S v Hassen supra 248d-j.

$16 S v$ Kotze supra par 21. But compare Du Toit et al 24-131, and Zeffertt, Paizes and Skeen The South African Law of Evidence (2003) 764.

17 This must be read as being subject to section 35(5) of the Constitution of the Republic of South Africa Act 108 of 1996, hereinafter "the Constitution". This aspect will be discussed later.

18 This approach has been criticised. See Naude 199811 SACJ 219; Braithwaite, Fisse and Geis "Covert Facilitation and Crime: Restoring Balance to the Entrapment Debate" 1987 43(5) Journal of Social Issues 5 7; and Bohler 199912 SACJ 328.

19 See, eg, S v Makhanya 20023 SA 201 (N) 206h-i; S v Reeding 20052 SACR 631 (C) 637ij; and S v Dube 20001 SACR 53 (N). See also, Du Toit et al 24-134; and S v Ogudo 20011 SACR 560 (W) 566.

$20 S$ v Ogudo supra $565 \mathrm{~h}-567$.

$21 \quad S v$ Dube 20001 SACR 53 (N) 70-71.

22 Cape Town City Council v SAMWU c367/98 2000 ZALC 106. 
Section 252A (1) provides further, that the entrapment operation must be carried out to "detect, investigate or uncover the commission of an offence or to prevent the commission of an offence" - for the section to apply. Du Toit et al provide the example of traps which operate in order to instigate or encourage the commission of crime, as falling outside of the statutory purposes, and thus outside of the ambit of section $252 \mathrm{~A}$. $^{23}$

Section 252A(1) envisages two types of traps. The first being a trap where an individual is just given an opportunity to commit a crime, and the second being a trap which goes beyond merely providing such an opportunity.

Evidence obtained from the first type of trap, namely one which does not go beyond providing an opportunity for the commission of an offence, is automatically admissible. The presiding officer has no discretion to refuse to admit it in terms of section 252A - although the possibility of exclusion in terms of section 35(5) of the Constitution or in terms of the common law remains. ${ }^{24}$ Louw considers that this formulation is clumsy and unduly restrictive. ${ }^{25} \mathrm{He}$ further argues that evidence should be automatically admissible only if the trap is fair. ${ }^{26}$ Naude argues that evidence obtained from entrapment should only be admitted where an entrapment warrant is obtained in advance of the trapping. ${ }^{27}$ Du Toit et al argue that in so far as the section provides for mandatory admission of evidence, which may fall within the scope of section 35(5) of the Constitution, it may be subject to constitutional challenge.$^{28}$ However, the court has found that section $252 \mathrm{~A}(1)$ must be read as being subject to the duty to exclude the evidence in terms of the Constitution, where the requirements of section 35(5) are met. ${ }^{29}$ It is submitted, that this is the preferable approach, as it is consistent with the general principle of constitutional interpretation - known as "reading in". ${ }^{30}$

\section{Section $252 \mathrm{~A}(2)$}

If the trap goes beyond simply providing the opportunity for the commission of an offence, the presiding officer has discretion as to whether to admit evidence obtained therefrom or not. Whether a trap is regarded as going beyond providing the opportunity for the suspect to commit the offence, is to be decided in terms of a list of thirteen factors set out in section 252A(2)(a)(n). These factors are largely a codification of common-law factors relevant to identifying unfair traps. ${ }^{31}$ The section is, however, confusing - in that the factors listed include some which come into existence before, and some which come into existence after the occurrence of the trap. ${ }^{32}$ Furthermore, some factors refer to general considerations, some to issues specific to the

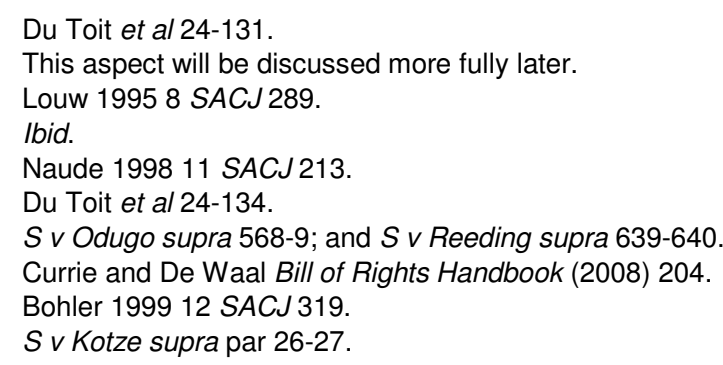


trap in question, and some are not logically linked to the enquiry into whether the trap went beyond creating the opportunity for the commission of the offence. ${ }^{33}$ Bronstein comments that the list of factors "float around aimlessly in the legislation ...", but considers that "judicial officers will give meaning to the subsection through the application of the principles on a case-by-case basis". ${ }^{34}$ Du Toit et al believe, however, that the section is inadequate to give sufficient guidance to the courts - to enable them to provide the necessary certainty and meaning to this area of the law. ${ }^{35}$ The court in $S \vee$ Odugo agreed.

The factors listed in section $252 \mathrm{~A}(2)$ are:

(a) Whether permission was obtained from the director of public prosecution's office, if required, and if so, whether the director of public prosecution's guidelines were followed.

(b) The nature of the offence, including whether the security of the state, the safety of the public, the maintenance of the public order, or the national economy is seriously threatened thereby, the prevalence of the offence in the area concerned, and the seriousness of the offence. ${ }^{38}$

(c) The availability of other techniques of investigation to obtain evidence of the offence. ${ }^{39}$

(d) Whether an average person in the same position would have been induced to commission of the offence. ${ }^{40}$

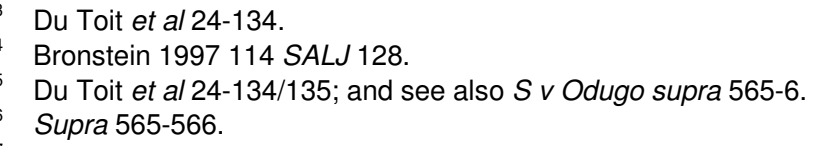

S $252 \mathrm{~A}(2)(\mathrm{a})$. The section refers to the "attorney-general", but this office has been replaced by that of the director of public prosecutions. S $252 \mathrm{~A}(4)$ authorises directors of public prosecution to issue guidelines regarding the conduct of entrapment operations in their jurisdictions. The National Prosecuting Authority has also issued general guidelines to prosecutors, which are contained in policy directives, and which came into effect on 1 June 2000. In S v Makhanya 20023 SA 201 (W), the court held that section 252A(2)(a) was not mandatory. In $S \vee$ Reeding supra, the court held that deviation from any such directives issued would not necessarily render the trial unfair. A similar view was held in $S \vee$ Zurich 20101 SACR 171 (SCA), where the court also held that any such directives did not constitute legal or statutory requirements, as contemplated in section $252 \mathrm{~A}(3)$ (b)(ii)(aa).

38 S 252(2)(b). Victimless crimes, by nature, are considered particularly difficult to solve by ordinary investigative methods. There are two possible ways to view the consideration of the seriousness of the crime. On the one hand, the more serious the offence, the less one would want to exclude evidence which might secure the conviction of those guilty. On the other hand, the more serious the offence, the more serious the consequences flowing from a conviction, and thus the more one would want to ensure that the integrity of the judicial process is untainted, and not associated with "dirty tricks".

39 S 252A2(c). In R v Clever 19674 SA 256 (RA), the court held that untargeted traps which just offer "bait" in the form of an opportunity to commit a crime, will often not be acceptable, because law enforcement should have other means available to apprehend suspects - eg, by intense surveillance. Louw "Act 85 of 1996: Legislative Regulation of Evidence Obtained by Police Trap" 199710 SACJ 186 189, suggests that this is an unreasonable restriction on law enforcement, in that law-enforcement officers should be able to use any investigative technique to obtain evidence of crime, so long as it is fair.

$40 \mathrm{~S} 252 \mathrm{~A}(2)(\mathrm{d})$. This factor suggests that the test is objective, whereas the factors in sections $252 \mathrm{~A}(\mathrm{~h})$ and (i) suggest a subjective approach. This peculiar feature of the section is discussed by Louw 199710 SACJ 190. 
(e) The degree of persistence and the number of attempts to induce the commission of the offence. ${ }^{41}$

(f) The type of inducement, including the degree of any deceit, trickery or misrepresentation by the official. ${ }^{42}$

(g) The timing of the conduct, in particular whether the official instigated the offence or became involved in existing unlawful activity. ${ }^{43}$

(h) Whether the conduct involved an exploitation of human characteristics such as emotions, sympathy and friendship, or an exploitation of the accused's personal, professional or economic circumstances, to increase the probability of the commission of the offence. ${ }^{44}$

(i) Whether a particular vulnerability (like a mental handicap, or substance addiction) was exploited. ${ }^{45}$

(j) The proportionality between the involvement of the official, compared with that of the accused, including the degree to which the official was at risk compared to the accused, and the commission of any illegal acts by the official. ${ }^{46}$

(k) Any threats (express or implied) towards the accused. ${ }^{47}$

(I) Whether before the trap was set, there was reasonable suspicion that the accused had committed a similar offence. ${ }^{48}$

(m) Whether the official acted in good or bad faith. ${ }^{49}$

(n) Any other relevant factor. ${ }^{50}$

41 S 252A(2)(e). Begging and active persuasion by the trap, are generally indicators that the trap is improper. See $S \vee$ Van der Berg 20091 SACR 661 (C), where the accused resisted nine offers to sell him diamonds at half their normal price, but yielded on the tenth attempt. The trap was found to be unfair. See also $S$ v Matsabu 20091 SACR 513 (SCA), where the official made multiple attempts to persuade the accused to accept a bribe.

$42 \mathrm{~S} 252 \mathrm{~A}(2)(\mathrm{f})$. It is however accepted, that some degree of deceit and misrepresentation is an inherent feature of entrapment - see $S$ v Zurich 20101 SACR 171 SCA.

$43 \mathrm{~S} 252 \mathrm{~A}(2)(\mathrm{g})$. Generally, traps where the official instigated the offence will be regarded as more serious than those where he merely became involved in existing unlawful activity, to secure evidence.

$44 \mathrm{~S} 252 \mathrm{~A}(2)(\mathrm{h})$. This factor was considered important in S v Pektar 19883 SA 571 (A) 576D; and in $R \vee$ Vlok and Vlok 19541 SA 203 (SWA) 205, where the trap established intimate relations with the suspects in both cases.

$45 \mathrm{~S} 252 \mathrm{~A}(2)(\mathrm{i})$.

$46 \mathrm{~S} 252 \mathrm{~A}(2)(\mathrm{j})$.

$47 \mathrm{~S} 252 \mathrm{~A}(2)(\mathrm{k})$.

48 S 252A(2)(I). See $S \vee$ Sellem 19922 SACR 19 (A); and $S$ v Pektar supra, where the fact that the accused were serving suspended sentences was not regarded as sufficient to establish a reasonable suspicion - the courts rather considered this a fact that would render them more vulnerable to the trapping. See also $S$ v Mkhonto 20011 SACR 585 (C), where the only basis for suspicion was the appellant's previous conviction in respect of a similar offence. Bronstein 1997114 SALJ 127, advocates an approach which unequivocally excludes certain untargeted trap evidence. She argues that traps should only be used if there is a reasonable suspicion that the individual is involved in the crime, or where the untargeted trap allows the individual to put independent and methodical criminal design into operation (123). In this she differs from Louw 19958 SACJ 291, who argues that all untargeted traps should be outlawed.

$49 \mathrm{~S} 252 \mathrm{~A}(2)(\mathrm{m})$. See also Van der Merwe "The Good Faith of the Police and the Exclusion of Unconstitutionally Obtained Evidence" 1998 SAS 462. 
If the trap is found to go beyond providing the opportunity for the commission of the offence, the presiding officer has a discretion to refuse to admit the evidence obtained therefrom - if the evidence was obtained in an improper or unfair manner, and if the admission of the evidence would render the trial unfair or be otherwise detrimental to the interests of justice in terms of section $252 \mathrm{~A}(3){ }^{5}$

\section{Section $252 \mathrm{~A}(3)$}

There is thus a two-stage enquiry to determine the admissibility of evidence in terms of section $252 \mathrm{~A}(3)$. It firstly needs to be established whether the evidence in question was obtained in an improper or unfair manner; and secondly it must be established whether its admission would render the trial unfair, or would be otherwise detrimental to the interests of justice. ${ }^{52}$ The SCA has found, albeit obiter, that the two requirements should be read conjunctively. ${ }^{5}$

When considering these issues, the court is directed to weigh up the public interest against the personal interest of the accused, having regard to any applicable factors listed in section $252 \mathrm{~A}(3)$ (b)(i)-(iv) of the CPA, as well as any other relevant factor (section $252 \mathrm{~A}(3)(\mathrm{b})(\mathrm{v})$ ). The listed factors are: firstly, the nature and seriousness of the offence; secondly, the extent of the effect of the trap on the interests of the accused; thirdly, the nature and seriousness of any infringement of any fundamental right contained in the constitution; and lastly, whether the means used was proportional to the offence.

In deciding the nature and seriousness of the offence, the court is directed to consider the factors listed in section $252 \mathrm{~A}(3)(\mathrm{b})(\mathrm{ii})(\mathrm{aa})$-(dd). The listed factors are: firstly, whether the security of the state, the safety of the public, the maintenance of public order or the national economy is seriously threatened; secondly, whether it would be difficult to uncover, investigate and prevent the crime without a trap; thirdly, whether the crime is so frequently committed that special measures are required to uncover, detect and investigate it; and lastly, whether the offence is so indecent or serious, that the trap was justified.

In assessing the effect of the trap on the accused's rights, the court is directed to consider the factors listed in section 262A(3)(b)(iii)(aa)-(cc). Firstly, any deliberate disregard for the accused's rights or applicable legal and statutory requirements; secondly, the ease with which these requirements could have been complied with, having regard to the

50 S 252A(2)(n). Eg, in the case of $S v$ Makhanyana 20023 SA $201(\mathrm{~N})$, where trafficking in counterfeit bank notes was involved, the court considered other relevant factors to be the fact that the appellants were police officers using public resources to commit the crime, that the appellants had had an opportunity to withdraw from the operation, but persisted, and that the appellants planned to benefit financially at the expense of innocent citizens and the national economy.

51 S 252A(3). This discretion is subject to s 35(5) of the Constitution ( $S$ v Odugo supra 19), but compare the view of Paizes in Du Toit et al 24-131/134.

52 S v Odugo supra 565; S v Nnasolu 20101 SACR 567 (KZP) par 44-45.

$53 \quad S v$ Kotze supra. 
circumstances of the crime; and lastly, whether the prejudice suffered by the accused as a result of the unfair or improper conduct, was justified.

The court also directed to consider the nature and seriousness of any infringement of any fundamental right contained in the Constitution. ${ }^{54}$ This is with regard to whether - in the setting of the trap or the engagement of the undercover operation - the means used was proportional to the seriousness of the offence, ${ }^{55}$ and any other factor which the court considers should be taken into account. ${ }^{56}$

The factors listed in section $252 \mathrm{~A}(3)(\mathrm{b})$ are all factors which the court has grappled with in the broader context of deciding on the admissibility of unconstitutionally or otherwise improperly or illegally obtained evidence.

\section{Procedure}

The admissibility of evidence obtained as a result of entrapment will usually, but not always, be decided by way of a trial within a trial. Section $252 \mathrm{~A}(7)$ provides that "the question of whether evidence should be excluded in terms of subsection (3) may, on application by the accused or the prosecution, or by order of the court of its own accord be adjudicated as a separate issue in dispute". ${ }^{58}$

\section{THE CONSTITUTION OF THE RSA, 1996}

There may be circumstances where the evidence obtained as a result of the entrapment procedure does not fall to be excluded in terms of section 252A. Section 35(5) of the Constitution may nevertheless require that the evidence be excluded. ${ }^{59}$ Section $35(5)$ provides that evidence which has been obtained in a manner that violates any right in the bill of rights, must be excluded if the admission of that evidence would render the trial unfair, or be otherwise detrimental to the interests of justice. For section 35(5) to find application, there must be a breach of a constitutionally protected right, and the procurement of the evidence must be sufficiently closely and causally connected to the breach of a constitutional right. ${ }^{60}$ The court has no discretion to include such evidence, if to include it would render the trial unfair or be otherwise detrimental to the interests of justice. Thus, to the extent that section $252 \mathrm{~A}(3)$ (a) of the CPA makes the exclusion of such evidence discretionary, it is unconstitutional. ${ }^{61}$ The principle of reading down, however, requires that where possible the section be interpreted in a way

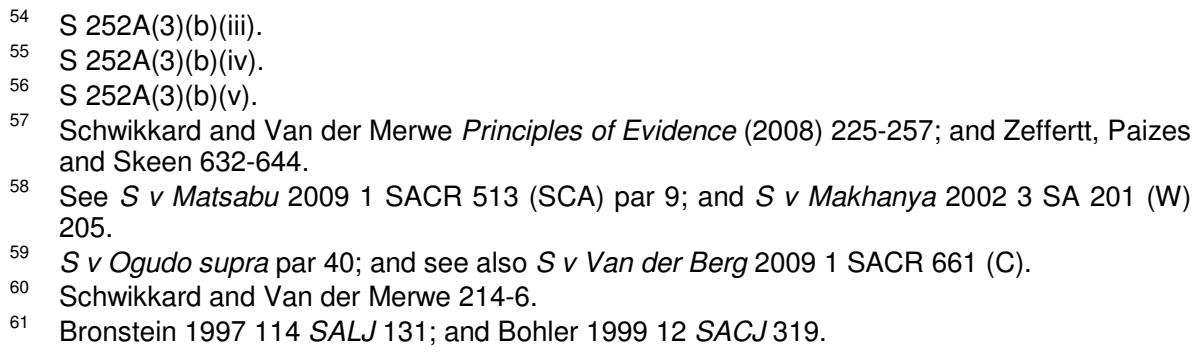

61 Bronstein 1997114 SALJ 131; and Bohler 199912 SACJ 319. 
that is consistent with the Constitution. This thus requires that section $252 \mathrm{~A}(1)$ be read as being subject to section $35(5) .^{62}$

\section{COMMON LAW}

Evidence obtained by a trap which does not go beyond the opportunity to commit an offence, and which does not meet the requirements of section 35(5) of the Constitution, may still be excluded in terms of the court's general common-law discretion to exclude improperly or illegally obtained evidence, for fairness and public policy considerations. ${ }^{63}$ An alternative formulation of the discretion, is that the court may exclude evidence where the prejudicial effect would outweigh the probative value of admitting the evidence. ${ }^{64}$ Whether this discretion developed to protect the right of the accused to a fair trial, or to protect the public interest - is a moot point. However, with the constitutional protection of the accused's right to a fair trial, the latter purpose is clearly the dominant one. ${ }^{65}$

In $S v$ Hammer, ${ }^{66}$ Farlam $\mathrm{J}$ refers with approval to Skeen's article in which he sets out the factors which would be useful in deciding whether to exclude evidence in terms of the common law. In the first place, he notes that there should be no presumption in favour of admission or exclusion of the evidence, and that the question of onus should not be introduced. ${ }^{67}$

He then refers to society's right to insist that law-enforcement officers themselves respect it, so that "a citizen's precious right to immunity from arbitrary and unlawful intrusion into the daily affairs of private life may remain unimpaired", ${ }^{68}$ and notes that "an untrammeled search for the truth should be balanced by discretionary measures". He adds, however, that such measures "should not be a direct intention to discipline the law-enforcement officials". ${ }^{69}$ The bona fides of the law-enforcement officers who acted unlawfully, and whether the unlawfulness affected the reliability of the evidence, must also be taken into account. Deliberate and reckless disregard for the law should not be tolerated, and neither should the deliberate cutting of corners for expedience. In addition, the presiding officer must take into account the ease with which the law could have been complied with, the nature of the offence, and the policy considerations behind it. Lastly, the court makes the point that unfairness to the accused should not be the only consideration, and that whether the administration of

\footnotetext{
Currie and De Waal 30.

S v Forbes 19702 SA 594 (C); S v Mushimba 19772 SA 829 (A) 840; and S v Hammer 19942 SACR 496 (C).

64 S v Mbatha 19852 SA 26 (D); S v Ramgobin 19864 SA 117 (N); S v Holtshauzen 19832 SA 699 (D); and compare $S \vee$ Nel 19874 SA 950 (W).

$65 S v$ Kidson 19991 SACR 338 (W) 349b-c; and S v M 20022 SACR 411 (SCA).

$66 \quad 19942$ SACR 466 (C).

67 It is doubtful whether this remains the correct approach in the light of the SCA decision in $S$ $\checkmark$ Kotze supra. See later discussion.

68 S v Hammer supra 466.

69 Ibid. See also Wigmore A Treatise on the Anglo-American System of Evidence in Trials at Common Law 3ed (1940) 2183-4.
} 
justice will be brought into disrepute by the admission or exclusion of the evidence, is also relevant. ${ }^{70}$

\section{5}

\section{$S V K O T Z E^{71}$}

\section{Background}

The appellant was convicted on four counts of purchasing unpolished diamonds from a police officer, who was acting as an undercover agent in a covert police entrapment operation. He appealed unsuccessfully to the High Court, but was granted leave to appeal to the Supreme Court of Appeal against his convictions. The only ground of his appeal was that the magistrate had erred in admitting the evidence obtained as a result of the entrapment operation, as it should have been excluded in terms of section $252 \mathrm{~A}(3)$ of the Criminal Procedure Act. The appellant did not argue that the evidence should be excluded in terms of the Constitution, nor in terms of the common law.

The state conceded that the entrapment went beyond simply creating an opportunity for the commission of the offence, as envisaged by section $252 \mathrm{~A}(1)$. If the entrapment evidence had been excluded, there would have been no admissible evidence of the transactions giving rise to the conviction, which would therefore have to be set aside.

\section{Facts}

The police embarked on an undercover operation to address the problem of illegal diamond dealing in the Namaqualand area. As part of that operation, Inspector Terblanche moved to Port Nolloth on the pretext of having retired from the police force. His mission was to obtain evidence relating to unlawful diamond dealing. The appellant was a prominent member of the Port Nolloth community.

The appellant and the Inspector met on the day the Inspector moved into the town - 1 August 2000. He assisted him in finding accommodation. Their relationship developed to the point that it was close and friendly. The two men and their families got to know one another, and socialised together. The Inspector would regularly visit the appellant at his business. He telephoned him on the occasions of his family members' birthdays, to wish them well. $\mathrm{He}$ and his family visited the appellant and his family after church. They shared condolences on the loss of the Inspector's sister, and on the loss of one of the appellant's children. The Inspector confided with the appellant about concerns he had about his own health. The Inspector and his wife took a trip with the appellant's wife, to view the seasonal flowers in the area. However, the appellant never visited the Inspector at his own home - other than in connection with the illegal transactions that formed the basis of his conviction.

\footnotetext{
S v Hammer supra 499.

71 See fn 2 above.
} 
There were multiple illegal transactions - the first took place on 14 July 2001, the second on 7 September 2001, the third on 14 December 2001, and the last on 10 February 2002.

The Inspector's versions of the transactions, and the events leading up to them, indicate that while he had put out the initial bait (by mentioning that he had been visiting with a diamond cutter), the appellant had initiated all the transactions. The appellant, however, told a different story. He testified that he had been given the impression that the Inspector was in dire financial straits, and that he, as a particularly compassionate man, was eager to help out. He testified that the appellant had relentlessly raised the topic of illegal diamonds, despite the appellant begging him to desist. He testified that the Inspector had initiated the transactions, and that he had reluctantly become involved to help a man he considered to be his close friend.

\section{Judgment}

\section{Section 252A(6): Accused's procedural duty}

The SCA noted that the appellant had not been asked to state the basis upon which he was challenging the admissibility of the evidence which had been obtained as a result of the entrapment operation, as was provided for by section $252 \mathrm{~A}(6)$ of the CPA. The SCA noted that this was unfortunate, as the failure to require the accused to fulfill this procedural duty, had compromised the efficient resolution of the matter. This was because attention was not focused on pertinent matters, and lengthy and irrelevant cross examination had wasted the court's resources. The court held that it was important for magistrates to apply section $252 \mathrm{~A}(6){ }^{72}$

Watney comments that the magistrate's failure to invoke section $252 \mathrm{~A}(6)$ may have been because procedural law is loath to require an accused person to reveal his defence or strategy. He nevertheless supports the approach taken by the SCA ${ }^{73}$ as I do. The accused's right to a fair trial is not compromised by requiring him to disclose the basis on which he challenges the admissibility of the entrapment evidence. This is akin to the overall procedural duty an accused has to introduce his defence in order for the prosecution to disprove it, or to set forth the reason he contends a confession is admissible. ${ }^{74}$

\section{Section 252A(6): Onus}

Section 252A(6) provides that while the accused must "furnish the grounds on which the admissibility of the evidence is challenged", the burden of proving that the entrapment evidence is admissible, rests with the prosecution, and that it must be discharged on a balance of probabilities. The section also requires the court to alert an unrepresented accused to the issues surrounding the admissibility of such evidence.

\footnotetext{
S v Kotze supra 111.

73 Watney "Some Comments on Entrapment" 20104 TSAR 835840.

74 Schwikkard and Van der Merwe 260.
} 
The SCA considered whether this section was unconstitutional, in so far as it only required the state to discharge the onus upon it to show the admissibility of the evidence on a balance of probability. It deviated from the approach taken by the court in $S v$ Reeding, ${ }^{75}$ finding that the lower standard of proof required of the state was incompatible with the constitutional jurisprudence regarding the rights of the accused - particularly the presumption of innocence and the right to silence. The SCA held that the Constitutional Court had established that these rights meant that the guilt of an accused person must be established beyond a reasonable doubt. The SCA compared the case where an accused incriminated himself by way of a confession, with the case where an accused incriminated himself as a result of his participation in an entrapment exercise, and found that there was no practical difference between them, as both cases involved the proof of facts necessary to secure the admission of the evidence, in order to prove the guilt of the accused. ${ }^{76}$ Accordingly, the court held - prima facie and in the absence of argument on the point - that the standard of proof that the state had to meet was that of proof beyond a reasonable doubt. In casu, the SCA found that this standard had been met by the state, and thus that its finding in this regard therefore did not affect the outcome of the appeal. ${ }^{77}$

Although this statement was made obiter, the court in the case of $S v$ $N_{a i d o o^{78}}$ held that the question had been decided definitively by the Supreme Court of Appeal. It found the dictum to be sound and in accordance with our common law and constitutional jurisprudence. ${ }^{79}$ There can be little doubt that this is correct, since the evidence obtained from an entrapment operation - like that of a confession - will invariably be decisive in determining the outcome of the trial. ${ }^{80}$

\section{Section $252 A(1)$}

The SCA heard the case on the basis that the trap had gone beyond providing an opportunity for the commission of the offence, because this point was not contested by the state. ${ }^{81}$ The court expressed the view that it was not, however, convinced that this was in fact the position.

The SCA emphasised that the mere fact that a trap is found to go beyond providing an opportunity for the accused to commit the offence, does not in itself render the trap "improper or imply that some taint attaches to the evidence obtained thereby". ${ }^{2}$ The court held that it simply meant that the evidence so obtained is not automatically admissible in terms of section $252 \mathrm{~A}(1)$, and so the judicial officer must exercise a discretion in this regard. However, the court added, that it does mean that some "doubt [is cast] on

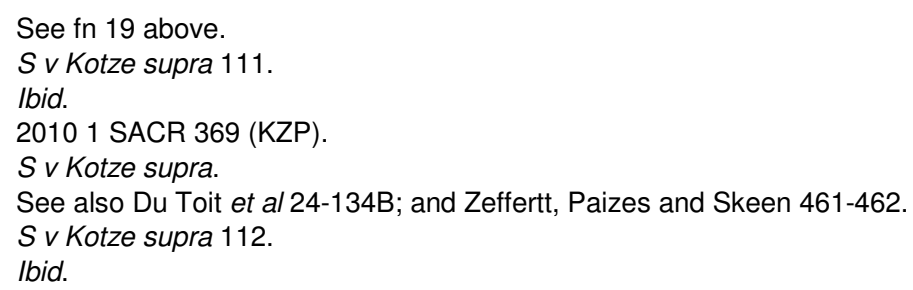


the propriety of the trap and the evidence obtained thereby, so that the situation requires further scrutiny before the evidence is admitted". ${ }^{83}$

The SCA commented obiter on the factors that he court is obliged to take into account in deciding whether a trap goes beyond creating the opportunity for the commission of an offence. The court held that, although the list had been criticised as potentially confusing, the apparent confusion was more apparent than real, provided one reads the section in a holistic manner and one does not just "peer at the language" ${ }^{\text {" }}$ out of context. The SCA found that the clear intention of the legislature was to identify factors which would be relevant to determining whether evidence obtained from a trap should be admissible without further enquiry, or whether more careful scrutiny is required before determining this to be so. The SCA held that the list of factors should therefore be viewed holistically and weighed cumulatively, because the different factors "may point toward different answers" ${ }^{85}$ The SCA confirmed its decision in $S v$ Hammond ${ }^{86}$ by finding that not all of the listed factors need be considered in every case. The SCA held that, because not all of the factors would necessarily be relevant in every case, the list should not be regarded as a check-list. Only evidence relevant to determining whether the trap went beyond simply creating the opportunity for the commission of the offence, needs to be analysed to ascertain "whether the conduct of the trap goes beyond the limits set by the legislature", ${ }^{87}$ Watney considers that this interpretation is inconsistent with the express wording of section $252 \mathrm{~A}(2)$, especially when compared to the wording used in section $252 \mathrm{~A}(3)$ - which expressly provides that only factors which are applicable need be considered.

\section{Section $252 A(3)$}

Section 252A(3) provides that the court has a discretion to exclude evidence, if the evidence was improperly or unfairly obtained, and where the admission of such evidence would render the trial unfair or would be otherwise detrimental to the administration of justice. In considering this section, the SCA held that it was not clear whether the section required that it should be established, both that the evidence had been improperly or unfairly obtained and that the admission of such evidence would render the trial unfair or be otherwise detrimental to the administration of justice, before the evidence be found to be admissible. The SCA, however, expressed the obiter view, that it would seem so because the two criteria are joined conjunctively in the section. ${ }^{89}$

The SCA also commented on the fact that the language of the section was discretionary, holding that, although the language of section $252 \mathrm{~A}(3)$ suggests that the exclusion of such evidence is discretionary ... but that in

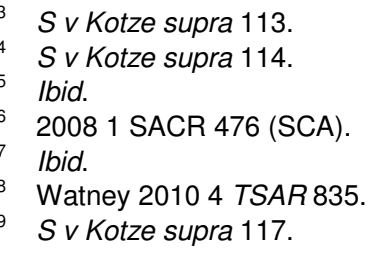


so far as there is a discretion, it is only a narrow one. The court held that "the power of the court to exclude the evidence where the relevant circumstances are established will ordinarily be coupled with a duty to exclude it". ${ }^{90}$

One presumes that the source of the duty to exclude the evidence that the SCA refers to, is the Constitution - but the judge implies that there may be circumstances where there is not a duty to exclude evidence, when to do so would render the trial unfair or be otherwise detrimental to the interests of justice. This cannot be so, because if a constitutional right has been violated, section 35(5) of the Constitution is applicable, and the court is compelled to exclude the evidence. If to admit it would render the trial unfair or be otherwise detrimental to the interests of justice. Perhaps this is what the learned judge meant, when he referred to a narrow discretion.

\section{Finding}

The SCA confirmed that the lower courts had correctly rejected the appellant's version, and found that he had been a willing participant - even the dominant player - in the illegal transactions, which were prevalent in the area and could not easily be detected by other means. The SCA noted that there were difficulties with the Inspector's evidence - but held that this did not detract from the overall conclusion that the appellant had been a willing and savvy participant, and that the Inspector had not done anything improper or unfair to induce the appellant to commit the crimes. ${ }^{91}$ The court also took into account that prior approval of the director of public prosecutions had been obtained, and that non-compliance with aspects of the directives did not impact on the fairness of the trap. The SCA found that the average person in the position of the appellant would not have succumbed to the temptation to commit the offence, since the profit involved was small. Furthermore, the police had had good reason to suspect the appellant to be involved in the illegal diamond trade by other evidence prior to the setting of the trap. The SCA also considered the factors set out in section $252 \mathrm{~A}(3)$ and concluded that the admission of the evidence would not render the trail unfair or be otherwise detrimental to the interests of justice.

Accordingly, the SCA found that the evidence obtained as a result of the entrapment had been properly admitted, and the appeal was dismissed.

\section{6}

\section{S V ZURICH ${ }^{92}$}

\section{Background}

The appellant had been convicted in a regional magistrate's court of two counts related to the illegal trade of elephant tusks. On appeal to the Northern Cape High Court, one of the convictions was set aside, but the

\footnotetext{
S v Kotze supra 116.

$91 \quad S v$ Kotze supra 117-118. See also $S$ v Hayes 1998 1 SACR 625 (O); and S v Hammond 20081 SACR 476 SCA, where "problems" with the trap evidence were not held to be relevant to the overall enquiry into the admissibility of the entrapment evidence.

9220101 SACR 171 (SCA).
} 
other was confirmed. The sentence remained the same. The appellant then appealed to the SCA. The evidence supporting his conviction had been obtained as a result of entrapment, and the appellant appealed on the basis that the evidence obtained as a result of entrapment had been improperly admitted.

\section{Facts}

The SAPS launched an undercover operation in response to widespread criminal activities in the Upington area pertaining, inter alia, to unlawful dealing in protected species. Authority for the covert operation had been obtained from the director of public prosecutions in Kimberley. The appellant was one of the individuals who had been identified as a possible suspect, and Oberholzer was engaged as the undercover agent to investigate the matter and to secure relevant evidence against the appellant. During the course of the undercover operation, Oberholzer's credibility was called into question - and this threatened to expose the entire covert operation. In order to bolster his credibility, the police staged his false arrest. The authority for the bogus arrest was given by the office of the director of public prosecutions. The plan was for Oberholzer to approach the appellant (who was a practising attorney) for assistance, and in this way to secure his trust. A member of the appellant's office represented Oberholzer at the bail proceedings. None of the court officials (including the magistrate and prosecutor) were aware that the arrest was bogus, nor that the bail proceedings were a charade. Although the appellant did not represent Oberholzer himself, the incident was successful in founding a trusting relationship between them, which culminated in illegal acts.

\section{Argument and concessions}

On appeal to the Northern Cape High Court, the appellant conceded that the trap did not go beyond providing an opportunity for the commission of the offence, and thus that the evidence obtained therefrom was admissible in terms of section 252A(1). However, he appealed on the basis that the evidence obtained as a result of the entrapment operation, should have been excluded in terms of section 35(5) of the Constitution. ${ }^{93}$

In the SCA, the appellant conceded that section 35(5) had no application, because no constitutional rights had been violated. ${ }^{94} \mathrm{He}$ argued, however, that the evidence should be excluded in terms of the court's common-law discretion to exclude evidence improperly obtained. The appellant argued that the improperness consisted in the magistrate and the prosecutor concerned having been misled, and the judicial process having been abused by police officers in cooperation with the National Prosecuting Authority, in an attempt to bolster their entrapment operation. ${ }^{95}$

\footnotetext{
$S v$ Zurich supra par 7

$S v$ Zurich supra par 8.

Ibid.
} 
The respondent conceded that the investigative methods used by the SAPS were unacceptable, and conceded that the court had a common-law discretion to exclude improperly obtained evidence. The respondent argued, however, that the facts did not justify the exclusion of the evidence. ${ }^{96}$

\section{Judgment}

The court held that there was no doubt that it retained its common-law discretion to exclude improperly obtained evidence on the grounds of unfairness and public policy. ${ }^{9}$

The court reasoned that in the case before it, neither the police nor the prosecuting authorities had perpetrated an unlawful act against the appellant himself, but instead that the impropriety had been directed against the court, the magistrate and the prosecutors, who had been unwittingly involved in the bogus arrest and trial of the appellant. In so far as the appellant had been concerned, all that had happened was that a misrepresentation had been made to him that Oberholzer was an illegal diamond dealer, which had the limited purpose of persuading the appellant that Oberholzer might be interested in other illegal dealings as well. It was this which prompted him eventually to introduce Oberholzer to people involved in dealing in elephant tusks, which led to the activities for which the appellant was charged. The court held that a degree of misrepresentation is an inherent element of entrapment, and that the appellant was an attorney who was involved in criminal activities, which the police had great difficulty in exposing. The court held that the entrapment could in no way be said to have impacted on the fairness of the appellant's trial, and concluded that in these circumstances the admission of the evidence could not be said to have brought the administration of justice into disrepute. To the contrary, the court held, the exclusion of the evidence would have done so. ${ }^{98}$

Accordingly, the court held that the evidence had been correctly admitted, and declined to exclude it in terms of the Constitution or the common law. The appeal was thus dismissed.

In view of the lack of resources that our courts have for legitimate cases, and with reports of accused persons spending years awaiting trial, we submit that the court should have indicated its disgust at the outrageous waste of court resources with a bogus case - by excluding the trap evidence. Watney shares this view, saying that "it is disappointing that the SCA condoned the abuse of court processes to ensure the successful continuation of an undercover operation", especially since the majority of the factors laid down in the Hammer case and referred to with approval by the court, support the exclusion of the evidence. ${ }^{99}$

\footnotetext{
$S v$ Zurich supra par 9.

97 S v Zurich supra par 10. See also S v M 20022 SACR 411 (SCA) 431g; and S v Hammer supra 466.

$98 \quad S v$ Zurich supra par 11.

99 See also Watney 20104 TSAR 842.
} 


\section{$7 \quad$ CONCLUSION}

What is evident from our discussion is that the use of traps is an important tool for the prevention and detection of crime. What is also clear, however, is that there is a fine line between fair and unfair entrapment, and that the use of entrapment must be carefully controlled so as to ensure that the rights of the accused are not eroded and that the administration of justice is not brought into disrepute. The appropriate remedy to control the use of entrapment is the exclusion of evidence in such circumstances, and it is appropriate that the courts have a wide discretion in this regard. It is our submission, however, that the rules regulating the admission of entrapment evidence are unnecessarily confusing, clumsy and complex. We are not alone in this view.

100 Du Toit et al 24-135; and see also S v Dube supra 73a-c. 